\begin{tabular}{|c|c|}
\hline$\xi$ & $\begin{array}{c}\text { International Journal of Current Research } \\
\text { and Academic Review }\end{array}$ \\
\hline $\begin{array}{l}\text { EXCELLENT } \\
\text { PUBLISHERS } \\
\end{array}$ & $\begin{array}{c}\text { ISSN: 2347-3215 (Online) Volume } 7 \text { Number } 4 \text { (April-2019) } \\
\text { Journal homepage: http://www.ijcrar.com }\end{array}$ \\
\hline
\end{tabular}

doi: https://doi.org/10.20546/ijcrar.2019.704.003

\title{
Effect of Storage Structures and Storage Period on Grain Quality of Maize (Zea mays L.): The Case of West Shawa Zone, Bako, Ethiopia
}

\author{
Fufa Negasa $^{1}$, Aberra Solomon ${ }^{2}$ and Demissie Girma ${ }^{3}$ \\ ${ }^{1}$ Ambo Agricultural Research Center, P.O. Box: 37, Ambo, Ethiopia \\ ${ }^{2}$ Department of food Science and Post-Harvest Technology, Haramaya Institute of Technology, Haramaya University, \\ P.O. Box: 138, Dire Dawa, Ethiopia \\ ${ }^{3}$ Holleta Agricultural Research Center, P.O. Box: 31, Holleta, Ethiopia
}

*Corresponding author

\section{Abstract}

Maize is one of the most important staple foods and the basis of diet for Ethiopian's. The present study was conducted to compare the effectiveness of traditional (Gombisa and Sack) and of hermetic bag storage methods concerning quantitative and qualitative losses after $0,2,4$ and 6 months of storage. The design was arranged in $3 \times 4$ factorial fashions. Quality of maize grains (variety: Bako Hybrid-661) stored in the three storage types (Gombisa, Sack and Hermetic Bag) for 6 months studied was in Bako, Ethiopia. Nutritional quality values (total protein, total fat, total fiber, total ash, and utilizable carbohydrate) the samples were analyzed for grain quality deterioration over time. Crude protein, Crude fat, Crude fiber, Crude Ash and total carbohydrate contents was influenced significantly $(\mathrm{P}<0.05)$ by storage type in Gombisa. Total protein, total fat, total fiber, total Ash and utilizable carbohydrate contents was significantly $(\mathrm{p}<0.05)$ influenced by storage periods. Initially total protein was high $8.9 \%$ and dropped significantly to $6.2 \%$ in Gombisa in six months of storage periods. Maximum value of total ash was recorded at initial and dropped significantly to $1.1 \%$ at the end of six months. The study shows maize grains quality losses in Gombisa and Sack might be due to relative humidity, temperature, moisture content were suitable for storage insects infestation and fungal contamination. As a result of this research, the Hermetic bag was determined to be more appropriate for maintaining grain quality for longer.
\end{abstract}

\section{Introduction}

Maize (Zea mays L.) is the third most important crop after rice and wheat cultivated in the world and occupying more than 120 million hectare of cropland annually (Marta et al., 2017). Maize is one of the most important food crops and provides at least $30 \%$ of the food calories to more than 4.5 billion people in 94

\section{Article Info}

Accepted: 04 March 2019

Available Online: 20 April 2019

\section{Keywords}

Quantitative loss; Qualitative loss; Biochemical analysis; Traditional storage; Maize. 
cellulose and lignin (3.3\% dry base), total sugar (2.58\% dry base) and total carotenoids (30 mg kgG1). However, maize grain suffers from quantitative and qualitative losses during storage. Various studies undertaken in subSaharan Africa to estimate maize (Zea mays L.) grain losses in traditional storage practices have shown that the losses are generally high (Befikadu et al., 2012). From harvest to consumer market, maize grain postharvest losses in Africa are estimated to range 14 to $36 \%$ (Tadale, 2012; Tadale et al., 2011). Grain storage container being used by majority of farmers in Jimma zone (more than 97\%) are traditional ones that couldn't protect the stored grain from deterioration. Grain losses occur due to several factors(Ape et al., 2016). The main causes of losses are improper storage structures (Niaz, and Dawar, 2009) and insect pest damage. According to (Sharma et al., 2007) the primary factors affecting the grains during their storage are moisture, temperature and relative humidity of the environment, then the negative conditions such as fungi growth, germination, decay (moldy), rancidity (bad smell) do occur. Other maize deteriorating agents for maize are rodents, insect pests and molds. Primary and secondary factors lead to chemical changes (nutritive and sanitary parameters), weight loss, insect damage and finally to changes in the maize quality (Niamketchi et al., 2016). The full losses resulting with deterioration are about $25-30 \%$ of the stored food grains (Gueye et al., 2011). The studies of (Suleiman et al., 2013) showed that 'Infection of maize grain by storage fungus results in discoloration, dry matter loss, chemical and nutritional changes and overall reduction of maize grain quality'. It has been reported by (Fandohan et al., 2003) that storage fungi contributes to loss of more than $50 \%$ of maize grain in tropical countries, and ranks second after insects as the major cause of deterioration and loss of maize. Traditional storage practices do not guarantee protection against major storage pests, grain quality of staple food crops, leading to higher percentage of grain losses, particularly due to post-harvest insect pests and grain pathogens (Sharon et al., 2014). The patterns of storage temperature, relative humidity and maize grain's associated insect pests and fungi which lead to quantitative and qualitative losses in the traditional and modern storage structures over storage periods in Bako was not exactly known and documented. Maize weevil, angoumois grain Moth, Sitophilus granurius and Tribolium castanum were identified in this work as the major insect pests that attacks maize grains during 6 months of storages in Gombisa Sacks and Hermetic bag. In view of limited information, in this paper the extent of maize grain nutrient quality losses in traditional storage containers (Gombisa and Sacks) Hermetic bag and over 6 months of storage are stated.

\section{Materials and Methods}

\section{Description of the study area}

This study was conducted at Bako Agricultural Research Center located in East Wollega Zone of the Oromia Regional State, western Ethiopia at an altitude of 1650 meters above sea level (m.a.s.l). Bako lies at $9^{0} 6^{\text {ee }}$ north latitude and $370^{\circ} 9^{\text {ee }}$ east longitude in the sub-humid ecology of the country $260 \mathrm{~km}$ west of Addis Ababa and $8 \mathrm{~km}$ away to the South from the main road to Nekemte. Average annual rainfall at this location is $1237 \mathrm{~mm}$. The rainy season extends from May to October and maximum rain is received in the months of July and August. Agro-ecologically, it has a warm humid climate with mean minimum, maximum and average air temperatures of 15,30 and $23^{\circ} \mathrm{C}$ respectively. The $\mathrm{RH}$ minimum, maximum and average of the area is $(49,74.7$ and $61.85 \%$ ), respectively (Source, Bako National maize Research Center Metrological data of 2016). The major annual and perennial crops of the area include maize, sorghum, teff, noug, hot pepper, haricot bean, sweet potato, mango, banana, and sugar cane in order of importance. The study was conducted for six (6) moths starting from harvesting time in December, 2017 to May, 2018 at Bako National Maize Research Center.

\section{Experimental plan and design}

The experiment was arranged in a factorial combination with two factors, storage types and storage period in complete randomized design with three (3) replications. Storage types have three levels i.e. Gombisa, Sack and Hermetic bag while storage period have four levels i.e. (T0, T1, T2, T3, T4, T5 and T6monthsof storage periods. Data were collected at every two months interval, including at the start of the study making up four levels for the factor storage period.

\section{Experimental materials}

The study material was BH-661 maize of variety harvested in December, 2017 and three types of traditional (Gombisa and Sack) and Hermetic bag storage types.

\section{Sampling of the stored grain}

A total of 90 samples of BH-661 maize variety were collected from each of storage methods periodically starting from the beginning of the storage $(0,2,4$ and 6$)$ 
months of storage periods). The initial maize samples from each storage structures were taken as a control at thebeginning of the storage. Each sample was taken by inserting the spear into the grain mass straight to the maximum depth from the top, middle and the bottom the storage.

\section{Biochemical analysis}

\section{Determination of ash}

Moisture and ash contents were carried out according to the relevant Association of Official Analytical Chemist (AOAC, 2012) methods for moisture (925.09) Procedure: A glass petri-dish was accurately weighed, after which an approximately $1.0 \mathrm{~g}$ of sample was added and reweighed and the weight recorded as (w1). This was kept in a vacuum oven for 3hour at the $105{ }^{\circ} \mathrm{C}$, the dish was removed from the oven, cooled and re-weighed and recorded as (w2). This process was repeated until a constant weight was attained. This process was repeated for all the samples, and the moisture content was calculated in percentage as follows: -

$$
\% \text { moisture }=\frac{\mathrm{W} 1-\mathrm{W} 2}{\text { weight of sample used }} X 100
$$

Ash contents were carried out according to the relevant Association of Official Analytical Chemist (AOAC, 2012) methods for ash (923.03). Clean empty silica crucibles were placed in a muffle furnace at $600^{\circ} \mathrm{C}$ for an hour till the constant weight was obtained and then transferred into desiccators to cool down to room temperature and then the weight of empty crucible was noted as quickly as possible to prevent moisture absorbance (W1). This crucible was labeled and two (2) gram of finely powdered test sample was placed in designated crucibles. The crucibles containing samples were then placed in a muffle furnace at $600^{\circ} \mathrm{C}$ for 7 hours. After the complete ignition the furnace was turned off. The crucibles was then transferred to desiccators cooled and re-weighed (W2). The difference of the two readings gave the weight of ash:-

Per cent ash will be calculated as follows:

$$
\text { Ash }(\%)=\frac{(W 2-W 1)}{\text { Sample weight }} \times 100
$$

Where: W1=Initial weight of empty crucible and W2= Final weight of crucible along with burnt sample

\section{Determinationprotein}

The crude protein content in the samples was determined from $\% \mathrm{~N}$ using a conversion factor of $6.25(\mathrm{~N} \times 6.25)$ according to method 920.152 (AOAC, 2006). Ground samples were analyzed for crude protein from each treatment using the micro-Kjeldahl methods. Sample of one gram (1gm) added into a Kjeldahl digestion flask. Catalyst mixture $\left(\mathrm{NaSO}_{4}\right.$ mixed with anhydrous $\mathrm{CuSO}_{4}$ in the ratio of 10:1.0g was added. After addition of $5 \mathrm{ml}$ of $\mathrm{H}_{2} \mathrm{SO}_{4}$, digestion flask was paced in the digester and the temperature was brought to $550^{\circ} \mathrm{c}$ allowed to digest for over $2 \mathrm{hr}$ until digestion is completed. The flask was removed and allowed to cool in a desiccator. After it was cooled, the content in flask was diluted by $30 \mathrm{ml}$ of distilled water followed by $25 \mathrm{ml}$ and concentrated $40 \%$ $\mathrm{NaOH}$ was added into the digestion flask to neutralize the acid and to make the solution slightly alkaline. The content was distilled immediately by inserting the digestion tube line into the receiver flask that contains 25 $\mathrm{ml}$ of $4 \%$ boric acid solution and about $150 \mathrm{ml}$ of distillated was collected. Finally, the distillate was titrated by a standard acid ( $0.1 \mathrm{~N}$ HCL). The $\%$ of nitrogen was converted to $\%$ of protein by using appropriate conversion factors $(\%$ of protein $=\mathrm{F} \times \mathrm{N})$. (Note: $1 \mathrm{ml}$ of $0.1 \mathrm{~N}$ acid $=1.401 \mathrm{mg} \mathrm{N}$ ). Per cent crude protein was calculated using the formula given below:

$\%$ Crude protein $=6.25 \times \% \mathrm{~N}$

$$
\text { Nitrogen }(\%)=\frac{(S-B) \times N \times 0.014 \times D}{\text { Wt of sample } \times V} \times 100
$$

$\mathrm{S}$ : sample titration reading, B: blank titration reading, $\mathrm{N}$ : normality of $\mathrm{HCl}, \mathrm{D}$ : dilution of sample after digestion, V: volume taken for titration, and 0.014 , mill-equivalent wt. of nitrogen.

\section{Determination fat}

Crude fat content was determined through the Soxhlet extraction Fat content was determined through the Soxhlet extraction method (AOAC, 2006) using $70 \mathrm{~mL}$ petroleum ether as the extraction solvent. Moisture-free samples (3 gm.) were wrapped in thimble prepared from Whatman filter paper No. 41 and weighed along with sample $\left(\mathrm{W}_{1}\right)$ before being introduced into the soxhlet apparatus. Cleaned and dried receiver flask was connected beneath the apparatus and one-third of it was filled with petroleum either and then fitted into the apparatus. Then, the apparatus heating rate was adjusted 
at a temperature of $60^{\circ} \mathrm{C}$ to give a condensation rate of 23 drops and extracted for 6 hours. When extraction will over, the thimble was removed from the soxhlet. Then the thimble was dried in an oven at $60^{\circ} \mathrm{C}$ overnight, then cooled in desiccators and weighed $\left(\mathrm{W}_{2}\right)$. The percentage crude fat was calculated by using the following formula:

$$
\text { Crude fat }(\%)=\frac{W 2-W 1}{\text { Sample weight }} \times 100
$$

Where: W1 = Initial weight of thimble along with sample before extraction

W2 = Final weight of thimble along with sample after extraction

\section{Determination fiber}

Crude fiber was determined using the methods of AOAC, 2006 (method number 32.10). Ground samples (3 gm.) was weighed (m1) placed in $500 \mathrm{ml}$ beaker. This digestion with $1.25 \%$ sulfuric acid and washed with water and further digested with $1.25 \%$ sodium hydroxide, filtered in coarse porous $(75 \mu \mathrm{m})$ crucible in apparatus at a vacuum of about $25 \mathrm{~mm}$. the residues left after refluxing was washed again with $1.25 \%$ sulfuric acid at near boiling point. Then, the residue was dried at $105{ }^{\circ} \mathrm{C}$ overnight, cooled in a desiccator and weighed (m2). After being dried the sample was ashed until ashing complete, cooled in a desiccator and weighed (m3). The total fiber was expressed in percentage as follows:-

$$
\text { Crude fiber }(\%)=\frac{m 2-m 3}{m 1} \times 100
$$

Where: $\mathrm{m} 1=$ the weight of sample $(\mathrm{gm}, \mathrm{db}), \mathrm{m} 2=$ the weight of sample ashing, $\mathrm{m} 3=$ the weight of sample after ashing $(\mathrm{gm}, \mathrm{db}) \mathrm{W} 2=$ Final weight of thimble along with sample after extraction

\section{Determination of carbohydrate}

Carbohydrate content was determined by calculating the difference of the total of percentage of protein, crude fat and ash from 100. Utilizable carbohydrate content $=100$ $-\Sigma(\%$ Moisture + Ash $\%+$ Protein $\%+$ Fat $\%+\%$ crude fiber). Results from percentages of ash, protein and fat were calculated in the dry material of kernels.

\section{Statistical analysis}

All the data collected were subjected to analysis of variance (ANOVA) by using the PROC GLM procedure (SAS institute, 2004) and difference among means were compared by the Least Significant Difference at 5\% level of significance (Steel, and Torrie, 1980). The correlation parameters were examined using Pearson's correlation coefficient using PROC CORR procedure of the SAS software (SAS Institute, 2004).

\section{Results and Discussions}

\section{Effect of storage type on chemical composition of maize grain}

All values of protein content were significant $(\mathrm{p}<0.05)$ to each other (Table 1). Protein content was 7.4, 7.7 and $8.2 \%$ for grain sampled in Gombisa, Sack and Hermetic bags, with significantly difference between the latter two only as the study obtained by (Befikadu et al., 2015). This could be due to loss damaged grains in the Hermetic bag associated with the lower level of insect infestation and microbial attack than Gombisa and Sack. All values were significant $(p<0.05)$ to each other (Table 2$)$. The values of crude fat for the different storage are 2.8, 2.9 and $3.1 \%$ for Gombisa, Sack and Hermetic bag with significant differences between Gombisa and Hermetic bag. This may also be because of fungi and insect infestation in the stored grain. Crude Ash was not significant $(\mathrm{P}<0.05)$ reduction as the storage in Sack and Hermetic bag. The crude fiber content of stored maize grains did not change with storage time. The carbohydrate content increased with increase of storage time (Table 2). Initially it was $71.3 \%$ and increased to $73.1,74.4$ and 75.6 after storage of 2, 4 and months as the study reported by (Sule et al., 2014). The increase in carbohydrate content can be attributed by insect damaged to the protein content of the stored grains and biochemical reaction of the stored grains.

\section{Effect of storage period on chemical composition of maize grain}

The crude protein content was $8.9 \%$ initially and the value decreased to $8.1,7.2$ and $6.8 \%$ after 2,4 and 6 months of storage (Table 1). The values were significantly different from each other. The reduction in crude protein can be attributed to insect infestation. 
Int.J.Curr.Res.Aca.Rev.2019; 7(4): 12-19

Table.1 Effect of storage type with storage periods on grain moisture content, total protein, fat, Ash and carbohydrate

\begin{tabular}{lcccccc}
\hline $\begin{array}{l}\text { Storage period } \\
\text { (Months) }\end{array}$ & MC (\%) & Crude protein (\%) & Crude Fat (\%) & Crude Ash (\%) & Crude Fiber (\%) & Carbohydrate (\%) \\
\hline ILD & $8.80 \pm 1.24^{\mathrm{d}}$ & $8.90 \pm 1.57^{\mathrm{a}}$ & $3.6 \pm 1.11^{\mathrm{a}}$ & $4.0 \pm 1.95^{\mathrm{a}}$ & $2.90 \pm 1.11^{\mathrm{a}}$ & $71.3 \pm 1.01^{\mathrm{d}}$ \\
2 & $10.20 \pm 1.43^{\mathrm{c}}$ & $8.1 \pm 1.90^{\mathrm{b}}$ & $3.2 \pm 1.02^{\mathrm{b}}$ & $2.8 \pm 1.20^{\mathrm{b}}$ & $2.8 \pm 0.19^{\mathrm{a}}$ & $73.1 \pm 3.15^{\mathrm{c}}$ \\
4 & $10.90 \pm 2.71^{\mathrm{b}}$ & $7.2 \pm 1.45^{\mathrm{c}}$ & $2.8 \pm 0.65^{\mathrm{c}}$ & $2.2 \pm 0.38^{\mathrm{c}}$ & $2.8 \pm 0.12^{\mathrm{a}}$ & $74.4 \pm 2.89^{\mathrm{b}}$ \\
6 & $12.10 \pm 2.91^{\mathrm{a}}$ & $6.8 \pm 1.04^{\mathrm{d}}$ & $2.3 \pm 0.14^{\mathrm{d}}$ & $1.1 \pm 0.08^{\mathrm{d}}$ & $2.8 \pm 0.10^{\mathrm{a}}$ & $75.6 \pm 3.78^{\mathrm{a}}$ \\
\hline LSD (5\%) & 0.45 & 0.34 & 0.16 & 0.34 & 0.42 & 0.8 \\
CV (\%) & 0.67 & 1.72 & 1.89 & 0.67 & 1.72 & 1.89 \\
\hline N & & 1.69 & & \\
\hline
\end{tabular}

Note: Values are means \pm standard deviation, Means followed by the same letters in the same columns and rows was not significantly different letters in the same columns and rows was not significantly different at $5 \%$ probability level

Table.2 Effect of storage type with storage periods on grain Total fiber Carbohydrate and Ash

\begin{tabular}{lcccccc}
\hline Storage types & MC (\%) & Crude protein (\%) & Crude Fat (\%) & Crude Ash (\%) & Crude Fiber (\%) & Carbohydrate (\%) \\
\hline Gombisa & $11.3 \pm 2.06^{\mathrm{a}}$ & $7.4 \pm 1.72^{\mathrm{b}}$ & $2.8 \pm 0.39^{\mathrm{b}}$ & $2.3 \pm 0.14^{\mathrm{b}}$ & $2.8 \pm 0.19^{\mathrm{a}}$ & $80.1 \pm 3.42^{\mathrm{a}}$ \\
Sack & $10.8 \pm 2.71^{\mathrm{b}}$ & $7.7 \pm 2.85^{\mathrm{b}}$ & $2.9 \pm 0.21^{\mathrm{b}}$ & $2.5 \pm 0.30^{\mathrm{b}}$ & $2.8 \pm 0.19^{\mathrm{a}}$ & $79.3 \pm 3.15^{\mathrm{b}}$ \\
Hermetic & $9.9 \pm 1.16^{\mathrm{c}}$ & $8.2 \pm 2.35^{\mathrm{a}}$ & $3.1 \pm 0.78^{\mathrm{a}}$ & $2.8 \pm 0.45^{\mathrm{a}}$ & $2.8 \pm 0.19^{\mathrm{a}}$ & $78.0 \pm 2.72^{\mathrm{c}}$ \\
LSD (5\%) & 0.45 & 0.34 & 0.16 & 0.34 & 0.42 & 0.8 \\
CV $(\%)$ & 2.2 & 4.3 & 2.22 & 3 & 2.71 & 1.8 \\
\hline
\end{tabular}

Note: Values are means \pm standard deviation, Means followed by the same letters in the same columns and rows was not significantly different letters in the same columns and rows was not significantly different at $5 \%$ probability level 
Table.3 Interaction effect of storage types and storage periods on grain moisture, total protein and fat

\begin{tabular}{|c|c|c|c|c|c|c|c|c|c|}
\hline \multirow{2}{*}{$\begin{array}{c}\text { Storage } \\
\text { Period } \\
\text { (Months) }\end{array}$} & \multicolumn{3}{|c|}{$\mathrm{MC}(\%)$} & \multicolumn{3}{|c|}{ Total Protein $(\%)$} & \multicolumn{3}{|c|}{ Total Fat (\%) } \\
\hline & Gombisa & Sack & Hermetic & Gombisa & Sack & Hermetic & Gombisa & Sack & Hermetic \\
\hline ILD & $8.80 \pm 1.15^{\mathrm{c}}$ & $8.80 \pm 1.15^{\mathrm{c}}$ & $8.80 \pm 115^{\mathrm{c}}$ & $8.90 \pm 1.7^{\mathrm{a}}$ & $8.90 \pm 1.7^{\mathrm{a}}$ & $8.90 \pm 1.7^{\mathrm{a}}$ & $3.6 \pm 1.15^{\mathrm{a}}$ & $3.6 \pm 1.15^{\mathrm{a}}$ & $3.6 \pm 1.15^{\mathrm{a}}$ \\
\hline 2 & $9.10 \pm 1.30^{\mathrm{c}}$ & $8.63 \pm 1.12^{c}$ & $8.80 \pm 1.15^{\mathrm{c}}$ & $8.2 \pm 2.35^{\mathrm{b}}$ & $8.5 \pm 2.3^{\mathrm{a}}$ & $8.0 \pm 1.9^{b}$ & $3.23 \pm 1.11^{\mathrm{a}}$ & $3.23 \pm 1.11^{\mathrm{a}}$ & $3.23 \pm 1.10^{\mathrm{a}}$ \\
\hline 4 & $11.5 \pm 1.22^{\mathrm{b}}$ & $10.23 \pm 1.17^{\mathrm{c}}$ & $10.07 \pm 1.18^{c}$ & $6.5 \pm 1.04^{\mathrm{d}}$ & $7.6 \pm 2.8^{c}$ & $7.6 \pm 2.8^{b}$ & $2.80 \pm 0.14^{\mathrm{a}}$ & $2.80 \pm 0.44^{\mathrm{a}}$ & $3.00 \pm 1.13^{\mathrm{a}}$ \\
\hline 6 & $12.2 \pm 1.42^{\mathrm{a}}$ & $11.53 \pm 1.22^{\mathrm{b}}$ & $10.63 \pm 1.22^{\mathrm{c}}$ & $6.2 \pm 1.54^{\mathrm{d}}$ & $7.3 \pm 1.72^{\mathrm{c}}$ & $7.4 \pm 1.72^{\mathrm{c}}$ & $2.20 \pm 1.44^{\mathrm{b}}$ & $2.40 \pm 0.14^{\mathrm{a}}$ & $2.53 \pm 0.16^{\mathrm{a}}$ \\
\hline $\operatorname{LSD}(5 \%)$ & 0.32 & & & 0.44 & & & 0.54 & & \\
\hline CV (\%) & 0.72 & & & 1.75 & & & 2.12 & & \\
\hline
\end{tabular}

Note: Values are means \pm standard deviation, Means followed by the same letters in the same columns and rows was not significantly different letters in the same columns and rows was not significantly different at $5 \%$ probability level

Table.4 Interaction effect of storage types and storage periods on grain Fiber, Carbohydrate and Ash

\begin{tabular}{cccccccccc}
\hline \multirow{2}{*}{$\begin{array}{c}\text { Storage Period } \\
\text { (Months) }\end{array}$} & Gombisa & Sack & Hermetic & Gombisa & Sack & Hermetic & Gombisa & Sack & Hetal Ash (\%) \\
\cline { 2 - 9 } ILD & $2.90 \pm 1.57^{\mathrm{a}}$ & $2.90 \pm 57^{\mathrm{a}}$ & $2.90 \pm 1.57^{\mathrm{a}}$ & $71.3 \pm 1.01^{\mathrm{e}}$ & $71.3 \pm 1.0^{\mathrm{e}}$ & $71.3 \pm 1.01^{\mathrm{e}}$ & $4.0 \pm 1.95^{\mathrm{a}}$ & $4.00 \pm 1.95^{\mathrm{a}}$ & $4.0 \pm 1.95^{\mathrm{a}}$ \\
2 & $2.6 \pm 1.16^{\mathrm{a}}$ & $2.50 \pm 1.16^{\mathrm{a}}$ & $2.7 \pm 0.14^{\mathrm{a}}$ & $73.2 \pm 3.15^{\mathrm{d}}$ & $73.4 \pm 3.15^{\mathrm{d}}$ & $73.2 \pm 3.15^{\mathrm{d}}$ & $2.60 \pm 1.16^{\mathrm{b}}$ & $2.67 \pm 2.21^{\mathrm{b}}$ & $2.77 \pm 1.57^{\mathrm{b}}$ \\
4 & $2.4 \pm 1.79 \mathrm{a}$ & $2.1 \pm 1.44^{\mathrm{a}}$ & $2.4 \pm 1.79^{\mathrm{a}}$ & $75.2 \pm 3.78^{\mathrm{b}}$ & $74.2 \pm 1.89^{\mathrm{c}}$ & $74.6 \pm 1.89^{\mathrm{c}}$ & $1.90 \pm 1.20^{\mathrm{c}}$ & $2.4 \pm 1.79^{\mathrm{b}}$ & $2.40 \pm 1.79^{\mathrm{b}}$ \\
6 & $1.9 \pm 1.20^{\mathrm{a}}$ & $2.0 \pm 1.38^{\mathrm{a}}$ & $2.3 \pm 0.14^{\mathrm{a}}$ & $76.2 \pm 3.99^{\mathrm{a}}$ & $75.4 \pm 3.78^{\mathrm{b}}$ & $74.2 \pm 1.89^{\mathrm{c}}$ & $1.00 \pm 0.94^{\mathrm{d}}$ & $1.20 \pm 0.94^{\mathrm{d}}$ & $2.40 \pm 1.79^{\mathrm{b}}$ \\
LSD (5\%) & 0.57 & & & 0.45 & & & & 0.47 & \\
CV(\%) & 2.2 & & & 1.8 & & & & & \\
\hline
\end{tabular}

Note: Values are means \pm standard deviation, Means followed by the same letters in the same columns and rows was not significantly different letters in the same columns and rows was not significantly different at $5 \%$ probability level 
Maximum crude fat $3.6 \%$ at the initial grain loading and the minimum was recorded during the last six months. Using of grains before this periods appropriate time. There was no significant $(\mathrm{P}<0.05)$ change seen in crude fiber throughout the storage periods. Maximum Ash content $4.0 \%$ was observed during initial loading and minimum values $1.1 \%$ was recorded at the last six months.

\section{Effect of storage type and storage periods on nutritional content of stored maize grains}

The results on chemical composition (crude protein, crude fat, total carbohydrate and ash) evaluated for $\mathrm{BH}-$ 660 maize grains stored in Gombisa sacks and Hermetic bag over 6months (Tables 1 and 2) are discussed below. The crude protein content of maize grain in the three storage structure was significantly different over six months of storage period $(p<0.05)$ (Table 3$)$. The values showed a decreasing trends 8.9 to $6.2 \%$ in Gombisa from initial to six months of storage periods. Significantly different and minimum crude protein content was obtained at the end of 6 months of storage in Gombisa and Sack storage. The reduction in crude protein can be attributed to insect infestation as obtained in the study of (Ape et al., 2016).

The values showed non-significant $(p<0.05)$ reduction to 2.3, 2.5 and $2.8 \%$ for grains stored in Gombisa, Sacks and Hermetic bag storage structures at the storage periods progressed as reported in the study result of Ape et al., (2016). Befikadu et al., (2015) disagreed that ash content showed an overall increase of $2 \%$ over the storage periods. This might be due insect attack to carbohydrate, protein and crude fat contents. Crude fat was not significantly different $(\mathrm{p}<0.05)$ in the three storage with storage periods. Maximum and significant increment was seen in Gombisa, Sack and Hermetic bag storage at the end of storage periods (Table 4). The increment in carbohydrate content can be attributed by insect damaged to the protein content of the stored grains and biochemical reaction that was happened during respiration to produces energy as observed in the study of (Befikadu et al., 2015). The interactive effect of storage periods and storage types was significant $(p<0.05)$ on the nutrient loss of stored grains.

\section{Conclusion}

Protein content was high at initial period and dropped significantly $(\mathrm{p}<0.05)$ from 8.90 to $6.2 \%$ in Gombisa, 8.90 to $7.30 \%$ for Sack and 8.90 to $7.4 \%$ for Hermetic bag at the six months. Maximum ash content $4.0 \%$ was recorded at initial loading and showed significant $(\mathrm{p}<0.05)$ reduction to $1.1 \%$ in Gombisa in the end of six months. Gombisa and Sack storage examined in this study are not able to prevent the damages grain as the storage period extends for more than six months. Statistically the values of total Fat was not significantly different $(\mathrm{p}<0.05)$ to each other throughout the storage periods. All the values were statistically $(\mathrm{P}<0.05)$ different from each other and the reduction in crude fat is attributed to insect and microbial attack in the storage Therefore, maize grains should not be stored for more than six under this area. Adoption of improved storage facilities like Hermetic bag storage will reduce maize grain losses, safe the resources required for maize grain production, minimizes: the maize nutrient quality deteriorations, mycotoxins and pesticide residues caused health risks and ultimately contributes to the improvement of food safety and food security of the region.

\section{Acknowledgements}

Authors acknowledge the financial support of Ethiopian Institute of Agricultural Research (EIAR). Authors are also grateful to Holeta Agricultural research Center and Debrezeyit Agricultural research Center for laboratory supports. In particular, my greatest thanks go to Mr. Biadge Kefale and OliLegasse for their unfailing devotion to duty and kind cooperation.

\section{References}

AOAC. (2006). Association of Official Analytical Chemists) Official Methods of Analysi, 17th ed.; Association of Official Analytical Chemists: Gaithersburg, MD, USA.

AOAC. 2012. Official Methods of Analysis. 19th Edition, Association of Official Analytical Chemists, Arlington, VA.

Ape, D. I., Nwogu, N., Uwakwe, E. 2016. "Comparative Proximate Analysis of Maize and Sorghum Bought from Ogbete Main Market of Enugu State, Nigeria', Greener Journal of Agricultural Sciences, Vol. 6, no.9, pp. 272-275.

Befikadu, D., Waktole, S., Solomon, A., Geremew, B. and Sethu, M. R. 2012. "Influence of Agroecologies, Traditional Storage Containers and Major Insect Pests on Stored Maize (Zea mays L.) In Selected Woredas of Jimma Zone", Asian Journal of Plant Sciences, vol.11 no.5, pp. 226-234. 
Befikadu, D.,Waktole,S., Solomon,A.,Geremew B.and Sethumadhavarao G. 2015. "Quality of grain maize stored in gombisa and sack in selected districts of Jimma Zone, Ethiopia", Vol. 4, no.4, pp. 192-196.

Fandohan, P., Hell, K., Marasas, W. F. O. and Wingfield M. J. 2003. "Infection of maize by Fusarium species and contamination with fumonisin in Africa "African Journal of Biotechnology, vol.2 no. 15 , pp. $570-579$.

Gueye, M. T, Seck, D. Ba, Hell, S., Sembène, K., Wathelet, Ma., J.P. and Lognay G. 2011. "Insecticidal activity of Boscia senegalensis (Pers.) Lam ex Poir. On Caryedonserratus (Ol.) pest of stored groundnuts" African Journal of Agricultural Research, vol.30, pp. 6348-6353.

Marta, H., Suryadi E. and Ruswandi. D. 2017. "Chemical Composition and Genetics of Indonesian Maize Hybrids", American Journal of Food Technology, Vol. 12, no. 2, pp. 72-85, 2017.

Michael, N., Hugo, De G.G., Zachary and Anani B. 2015."Effectiveness and Economics of Hermetic Bags for Maize Storage", 'Results of a Randomized Controlled Trial in Kenya' Agriculture in an introduced world, Italy.

Niamketchi, L., Chatigre, O., Konan, Y. and Biego, H. 2016. "Nutritive compounds evolution of postharvest maize (Zea mays L.) stored in granaries with bio-pesticides from rural conditions in Côte d'Ivoire" International Journal of Innovative Research in Technology and Science, vol.4, no.2, pp. 50-64.

Niaz, I. and Dawar, S. 2009. "Detection of seed borne my co-flora in maize (Zea mays L.)", Pakistan Journal of Biotechnology, vol. 41, pp. 443-451.
Rehman Z.U. 2006. "Storage effects on nutritional quality of commonly consumed cereals" Food Chemistry, vol. 95, pp. 53-57.

Sharma, S., Gambhir S. and Munshi S. K. 2007. "Changes in lipid and carbohydrate composition of germinating soybean seeds under different storage conditions", Asian Journal of Plant Science, vol. 6, pp. 502-507.

Sharon, M. E., Magdalene, C.V.A., Kavitha and Alagusundaram, K. 2014. "Grain Storage Management in India", Journal of Postharvest Technology, vol.02, no.01, pp. 012-024.

Steel, R. G. D., and Torrie J. H. 1980. "Principles and Procedures of Statistics", 2nd Ed. New York: McGraw-Hill.

Sule, I. E., Umoh, V.J., Whong, C.M.Z. and Abdullahi, O. Alabi. 2014. Chemical and nutritional value of maize and maize products obtained from selected markets in Kaduna State, Nigeria", African Journal of Food Science and Technology, vol.5 no.4, pp. 100-104, 2014.

Suleiman, R.A., Rosentrater, K.A. and Bern C.J. 2013. "Effects of deterioration parameters on storage of maize", A review: National Science Research, vol.3, Article ID 131593351.

Tadele, T., Kanampiu, F., Groote, H. D., Hellin, J., Mugo, S., Kimenju S. and Banziger M. 2011. "The metal silo", 'An effective grain storage technology for reducing post-harvest insect and pathogen losses in maize while improving smallholder farmers' food security in developing countries, Crop Protection, vol.30, no.3 pp. 240-245.

Tadele T. 2012. "Post-harvest losses in African maize in the phase of increasing food shortage", Food security, vol. 4, pp. 267-277.

\section{How to cite this article:}

Fufa Negasa, Aberra Solomon and Demissie Girma. 2019. Effect of Storage Structures and Storage Period on Grain Quality of Maize (Zea mays L.): The Case of West Shawa Zone, Bako, Ethiopia. Int.J.Curr.Res.Aca.Rev. 7(4), 1219. doi: https://doi.org/10.20546/ijcrar.2019.704.003 